\title{
PENERAPAN TEKNIK 3P (PELIPUTAN, PENULISAN, PENYUNTINGAN) DALAM PEMBELAJARAN MENULIS TEKS EDITORIAL PADA MAHASISWA STKIP SILIWANGI BANDUNG
}

\author{
Diena San Fauziya ${ }^{1}$, Alfa Mitri Suhara ${ }^{2}$ \\ STKIP Siliwangi Bandung \\ Surel: dienasanf@ikipsiliwangi.ac.id ${ }^{1}$ \\ alfa.suhara@ ikipsiliwangi.ac.id ${ }^{2}$
}

\begin{abstract}
ABSTRAK
Penelitian ini dilatarbelakangi oleh pentingnya kemampuan menulis pada mahasiswa dan inovasi dalam penerapan teknik pembelajaran. Adapun tujuan yang hendak dicapai adalah menguji efektivitas teknik 3P dalam pembelajaran menulis teks editorial pada mahasiswa Program Studi Pendidikan Bahasa dan Sastra Indonesia STKIP Siliwangi Bandung. Dalam lingkup lain, penelitian ini bertujuan untuk mendukung visi dan misi STKIP Siliwangi, yakni melakukan penelitian di bidang pendidikan yang berorientasi pada pengembangan ilmu dan teknologi untuk mengembangkan pembelajaran sehingga menghasilkan proses pembelajaran yang bermutu dan relevan dengan harapan dan kebutuhan masyarakat di era globalisasi. Dalam mencapai tujuan tersebut, metode penelitian yang digunakan adalah eksperimen dengan desain control group pretest-postest design. Dari hasil pengujian hipotesis yang dilakukan dengan program SPSS, diperoleh simpulan bahwa terdapat perbedaan yang signifikan antara nilai kemampuan menulis teks editorial di kelas yang menggunakan dengan yang tidak menggunakan teknik 3P. Simpulan ini dibuktikan dengan nilai signifikansi 0,000 dengan perhitungan uji t indenpendent sample teritorial.
\end{abstract}

Kata kunci: teknik pembelajaran, peliputan, penulisan, penyuntingan

\section{ABSTRACT}

The research background are the importance of the Students writing skills and innovation of learning technique application. This reasearch is conducted to test the effectiveness of $3 P$ techniques (coverage, writing, and editing) in writing editorial text in the major of Language educatian and Literature Studies STKIP Siliwangi Bandung. In another scope, this research aims to support the vision and mission of STKIP Siliwa-ngi, conducting research in the field of education oriented to the development of science and technology to develop the learning resulted to produce the quality learning process and relevant to the expectations and needs of globalization era society. The method used in this research is experiment with control group pretest-posttest design. The results of hypothesis testing conducted with SPSS program, it is obtained the conclusion that there is a significant difference between the value of the ability to write editorial text in the class that do or don't use the 3P techniques. This conclusion is evidenced by a significance value of 0,000 with the calculation of tidenentent sample of the theoretical sample.

Keywords: learning techniques, coverage, writing, editing 


\section{PENDAHULUAN}

Mengkaji dan meneliti ihwal menulis tidak pernah ada habisnya. Hal ini sekaitan dengan kenyataan bahwa menulis merupakan salah satu keterampilan berbahasa yang menjadi bukti nyata kemajuan peradaban. Semakin terampil seseorang menulis membuktikan bahwa ia semakin modern. Modernitas yang dimaksud dapat dinilai dari kualitas tulisan sebagai produk pemikiran penulis, sementara kuantitas tulisan tidak selalu menjadi sebuah jaminan. Apalagi, belakangan ini, penyebaran informasi di media massa, khususnya elektronik semakin bebas. Dengan demikian, potensi keterampilan menulis harus terus dipelajari.

Diantara begitu banyak jenis teks tulisan, terdapat salah satu jenis yang menarik, yakni teks editorial. Teks yang juga disebut sebagai tajuk rencana ini merupakan salah satu jenis teks yang tergolong kompleks. Dikatakan demikan karena tulisan ini tidak hanya memuat apa yang teramati melalui pancaindera seperti deskriptif, teralami melalui kisah seperti naratif, terungkapkan melalui pendapat seperti argumentatif, tetapi juga tercerminkan melalui ajakan seperti persuasif. Dalam teks yang mengandung komplesitas tersebut memunculkan adanya fakta dan opini dari sudut pandang tertentu.

Teks editorial ini biasanya muncul dalam majalah, koran, atau media massa cetak lainnya. Kekhasannya adalah bahwa jenis teks ini biasa ditulis oleh dewan redaksi sebagai pandangan media tersebut atas suatu permasalahan sebagaimana yang diuraikan Kosasih (2014, hlm. 282) bahwa editorial adalah kolom khusus dalam surat kabar yang berisikan tanggapan redaksi dari media yang bersangkutan terhadap satu peristiwa aktual. Namun demikian, dalam kurikulum pembelajaran bahasa, khususnya mengacu pada kurikulum 2013, jenis teks ini menjadi salah satu bagian dari kompetensi dasar yang harus dikuasai oleh siswa. Keadaan ini menjadikan teks editorial sangat penting untuk dipelajari.

Di samping apa yang telah diuraikan, berkenaan dengan teks editorial, Parisi
(2014) pernah melakukan penelitian. Penelitiannya mengenai keterampilan membaca, namun ditindaklanjuti dengan kegiatan menulis. Dari simpulannya dapat diketahui bahwa dalam kegiatan menulis teks editorial, siswa menjadi lebih selektif dalam memilih kata. Hasil penelitian tersebut menjadi salah satu dasar mengapa fokus dalam penelitian ini adalah teks editorial. Selain itu, sebagai calon-calon pihak yang akan mengajarkan teks editorial kepada siswa, mahasiswa STKIP Siliwangi dituntut mampu membuat teks tersebut sebagai bahan pemodelan. Apalagi, teks editorial sangat berhubungan erat dengan beberapa mata kuliah pilihan di Program Studi Pendidikan Bahasa Indonesia, yakni yang berkenaan dengan jurnalisitik.

Sebagai variabel yang akan mempengaruhi pembelajaran menulis yang diteliti, teknik 3P (Peliputan, Penulisan, dan Pe-nyuntingan) diujicobakan menjadi formula yang diyakini efektif memberikan pengaruh positif. Teknik 3P ini sebetulnya merupakan rancangan yang diadaptasi dari proses jurnalistik dalam proses penyusunan berita. Hal ini terinspirasi dari tulisan Mordekhay (2009). Meskipun demikian, teknik ini diadap-tasi menjadi sebuah teknik pembelajaran.

Alasan yang paling mendasari pengadaptasian teknik 3P ini dilatarbelakangi oleh beberapa hal, yakni pertama, pembelajaran menulis umumnya diawali oleh proses pengamatan melalui bahan dan media abstrak, seperti pemberian tema, teks, gambar, atau yang dianggap palingckonkrettadalah video. Sementara itu, melalui $3 \mathrm{P}$, proses menulis betul-betul diawali oleh bahan dan media yang konkret karena pembelajar secara langsung menemukan bahan tulisan melalui proses peliputan. Proses ini dapat dikatan menyerupai model menulis berbasis penelitian seperti yang telah dilakukan Cahyani (2010) namun lebih sederhana.

Kedua, setelah proses menulis dalam artian menuangkan ide dan gagasan, kebanyakan pembelajar melewatkan proses yang penting, yakni penyuntingan. Padahal, 
proses ini merupakan kewajiban penulis sebelum ia mempublikasikan tulisannya. Berdasarkan penelitiannya, Harahap (2014, hlm. 55) menyarankan bahwa keterampilan menyunting perlu diperhatikan secara sungguh-sungguh karena ini merupakan keterampilan yang penting.

Proses adaptasi yang dilakukan merupakan salah satu upaya dalam menciptakan dan mengembangan teknik pembelajaran inovatif agar pelaksanaan pembelajaran menjadi lebih variatif, menyenangkan, dan tepat sasaran. Hal ini dilakukan sekaitan dengan visi STKIP Siliwangi sebagai kampus yang inovatif.

Rumusan masalah yang diangkat dalam penelitian ini adalah "apakah teknik 3P (peliputan, penulisan, dan penyuntingan) efektif digunakan dalam pembelajaran menulis teks editorial pada mahasiswa Program Studi Pendidikan Bahasa dan Sastra Indonesia STKIP Siliwangi Bandung?" Sekaitan dengan masalah itu, penelitian ini bertujuan untuk menguji efektivitas teknik 3P dalam pembelajaran menulis teks editorial pada mahasiswa Program Studi Pendidikan Bahasa dan Sastra Indonesia STKIP Siliwangi Bandung. Hipotesis yang diajukan adalah hipotesis "Teknik 3P (Peliputan, Penulisan, Penyuntingan) efektif digunakan dalam pembelajaran menulis teks editorial pada mahasiswa Program Studi Pendidikan Bahasa dan Sastra Indonesia STKIP Siliwangi Bandung".

Teknik 3P ini merupakan teknik yang terinspirasi dan kemudian diadaptasi dari lapran praktikum Mordekhay (2009). Tek nik ini merupakan rankaian alur penulisan berita dalam sebuah surat kabar. Dengan mempertimbangkan berbagai aspek, seperti kesesuaian dan kelengkapan struktur pembelajaran menulis, rangkaian teknik tersebut diadaptasi untuk diterapkan dalam proses pembelajaran. Pada akhirnya, teknik 3P ini pada hakikatnya menjadi sebuah rangkaian tahap penulisan, meliputi peliputan, penulisan, dan penyuntingan.

Peliputan berhubungan dengan perencanaan dalam rapat proyeksi redaksi. Meliput dapat dilakukan dengan cara reportase, wawancara, ataupun riset kepustakaan. Penulisan tidak hanya meliputi hasil peliputan, tetapi juga dilengkapi dengan uraian mengenai tanggapan atas infomrasiinformasi yang berhasil dikumpulkan. Penyuntingan berhubungan dengan editing konten dan teknis. Kepaduan dan kesatuan isi teks (koherensi dan kohesi) menjadi dua bagian yang perlu diperhatikan dalam proses penyuntingan.

Berkenaan dengan teks editorial, Kosasih (2014, hlm. 282) mendefinisikannya sebagai sebuah artikel pokok dalam surat kabar yang merupakan pandangan redaksi terhadap peristiwa yang sedang menjadi pembicaraan pada surat kabar yang diterbitkan. Sementara itu, Sumadiria (2011, hlm. 82) mendefinisikan teks editorial atau tajuk rencana sebagai opini redaksi yang berisi aspirasi, pendapat, dan sikap resmi media pers terhadap persoalan potensial, fenomenal, aktual dan atau kontroversial yang terdapat dalam masyarakat. Dari dua pernyataan tersebut, dapat disimpulkan bahwa teks editorial merupakan artikel populer yang berisi tanggapan redaksi terhadap peristiwa, fenomena, atau isu yang sedang diperbincangkan.

Struktur editorial, meliputi (1) pengenalan isu, yakni sorotan peristiwa yang mengandung persoalan aktual sebagai bagian dari pendahuluan teks; (2) penyampaian argumen, yakni tanggapan-tanggapan terhadap peristiwa sebagai bagian dari pembahasan; (3) kesimpulan, saran ataupun rekomendasi, yakni pernyataan dalam menyelesaikan persolan yang telah dikemukakanascsebagaía bagian dari penutup (Kosasih, 2014, hlm. 285). Adapun kaidah teks editorial, meliputi (1) adanya penggunaan ungkapan retoris; (2) banyak menggunakan kata-kata populer sehingga mudah dipahami pembaca; (3) banyak menggunakan kata ganti tunjuk yang merujuk pada waktu, tempat, peristiwa, atau hal lain yang menjadi fokus ulasan; (4) banyak menggunakan konjungsi kausalitas atau hubungan sebab akibat sekaitan dengan adanya argumen yang dikemukakan; serta (5) banyak menggunakan 
konjungsi pertentangan sekaitan dengan masalah yang diangkat bersifat prokontra (Kosasih, 2014, hlm. 288).

Dari rangkaian teori yang ditemukan, berikut ini langkah teknik 3P dalam pembelajaran menulis teks editorial.

Tabel 1

Langkah Teknik 3P dalam Pembelajaran Menulis Teks Editorial

\begin{tabular}{|c|c|}
\hline $\begin{array}{l}\text { Tahapan } \\
\text { Formula }\end{array}$ & Langkah Kegiatan \\
\hline Peliputan & $\begin{array}{l}\text { 1. Mahasiswa } \\
\text { duduk } \\
\text { berkelompok } \\
\text { sebagai tim } \\
\text { redaksi } \\
\text { 2. Tim } \\
\text { merumuskan } \\
\text { topik-topik } \\
\text { peliputan } \\
\text { 3. Tim membagi } \\
\text { tugas (ketua } \\
\text { tim-penanggung } \\
\text { jawab, } \\
\text { penyusun } \\
\text { rancangan, } \\
\text { peliput, notula) } \\
\text { 4. Tim } \\
\text { melaksanakan } \\
\text { tugas }\end{array}$ \\
\hline Penulisan & $\begin{array}{l}\text { 5. Tim } \\
\text { mendiskusikan } \\
\text { hasil peliputan } \\
\text { 6. Masing-masing } \\
\text { anggota tim } \\
\text { membuat } \\
\text { kerangka } \\
\text { penulisan } \\
\text { 7.Setiap orang } \\
\text { menuangkan } \\
\text { hasil peliputan } \\
\text { ke dalam } \\
\text { bentuk teks } \\
\text { editorial dan } \\
\text { menanggapinya }\end{array}$ \\
\hline Penyuntingan & 8. Tim kembali ke \\
\hline
\end{tabular}

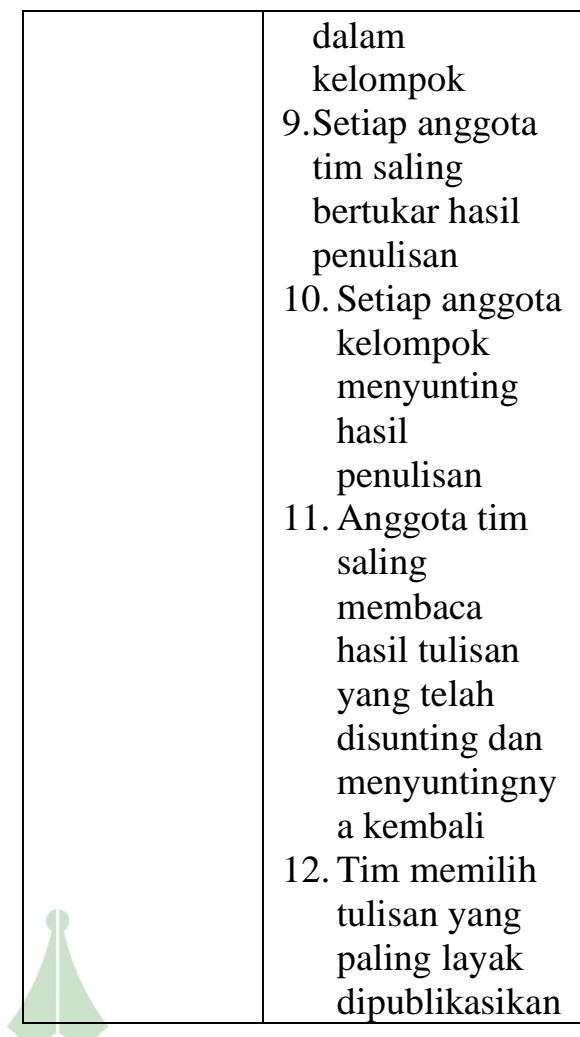

\section{METODE PENELITIAN}

Sesuai dengan rumusan masalah dan tujuan penelitian, metode penelitian yang digunakan adalah eksperimen karena berupaya membuktikan efektivitas suatu formula. Penelitian ini berupa quasi experiment dengan desain yang digunakan adalah control group pretest-postest design. Sampel dalam penelitian ini berjumlah 50 orang dengan pembagian 25 orang dalam grup kontrol dan 25 orang dalam grup eksperimen astra

Teknik pengumpulan data yang dilakukan berupa tes, meliputi tes awal dan tes akhir untuk masing-masing grup/kelompok. Instrumen yang digunakan adalah instruksi teks berupa menulis teks editorial dan pedoman penilaian yang dirumuskan dari teori menulis teks editorial, meliputi aspek kelengkapan unsur teks, kejelasan unsur teks, kesesuaian kaidah teks editorial, dan ketepatan penggunaan ejaan bahasa Indonesia. 
Teknik analisis data disesuaikan dengan prosedur penelitian kuantitatif, meliputi mengelompokkan data, mentabulasi data, menyajikan data, melakukan perhitungan statistik untuk menjawab rumusan masalah, melakukan perhitungan statistik pengujian hipotesis. Statistik yang dilakukan untuk pengujian ini adalah statistik inferensial. Adapun perhitungan statistik dilakukan dengan bantuan program SPSS.

\section{HASIL DAN PEMBAHASAN}

Teks editorial yang diperoleh dari hasil tes dianalisis dengan menggunakan instrumen pedoman penilaian. Berikut ini sampel analisis tes menulis teks editorial.

Salah satu teks berjudul "Eksistensi Bahasa Indonesia di Era Globalisasi". Merujuk pada pedoman penilaian yang telah disusun sebelumnya, judul ini terkategori mengandung daya kritis dan analitis. Alasannya adalah melalui judul itu subjek 9 mencoba mengemukakan daya kritis dan analitisnya mengenai keberadaan bahasa Indonesia di era global. Dengan demikian, tulisan subjek 9 ini telah memenuhi poin untuk judul yang mengandung daya kritis analitis dalam aspek kejelasan isi struktur. Tulisan ini juga menguraikan pengenalan isu disertai dengan data empiris. Penilaian ini tercermin dari pernyataan "Di era modern ini segala sesuatu serba instan. ... Masyarakat pengguna bahasa dimudah-kan dengan adanya teknologi." Argumenargumen yang dimunculkan juga sangat jelas, namun sayangnya tidak ditunjang dengan fakta-fakta yang jelas, sehingga poin menyajikan argumen yang kuatetidak terpenuhi. Meskipun demikian, tulisan ini telah mampu memberikan rekomendasi yang cukup eksplisit, yakni dengan adanya pernyataan "Dibutuhkan kesadaran serta kerja keras agar bahasa Indonesia tidak hilang dari jati diri bangsa Indonesia di era globalisasi ini".

Dari aspek kesesuaian kaidah, tulisan subjek 9 ini memenuhi semua poin. Di dalam tulisannya, terdapat konjungsi-konjungsi penyebab, ungkapan retoris, dan juga menggunakan kata-kata yang populer. Kon- jungsi penyebaban terlihat dari pernyataan pernyataan seperti "Teknologi berpengaruh besar terhadap kehidupan manusia dikarenakan perkembangannya yang sangat pesat." Meskipun demikian, secara ejaan, terutama dalam konsep kata, konjungsi dikarenakan tidaklah tepat karena dalam ragam tulis, konjungsi dikarenakan bukanlah kata yang tepat, dengan kata lain tidak baku. Dari aspek ejaan komponen lainnya, tulisan subjek 9 juga masih mencermin-kan ketidaktepatan penggunaan huruf, teru-tama huruf kapital, seperti masih menu-liskan bahasa Indonesia yang bukan nama pelajaran/mata kuliah/lainnya dengan menggunakan huruf kapital Bahasa Indonesia.

Selain sampel teks di atas, berikut ini sampel analisis untuk teks yang diperoleh dari hasil tes akhir kelas eksperimen. Judul teks adalah "Portofolio Sastra Berbasis Digital". Dengan judul tersebut, sudah tentu ia sangat mencerminkan daya kritis dan analitis karena mencoba mengemas informasi secara padat namun sarat makna. Tulisan ini pun mencerminkan semua poin kejelasan isi lainnya, seperti pengenalan isu, argumen yang kuat disertai fakta, serta menyajikan rekomendasi yang logis.

Di awal tulisannya terdapat pernyataan "Dunia pendidikan menjadi salah satu topik yang habis diperbincangkan. Sebagai contoh, mata pelajaran Bahasa dan Sastra Indonesia yang sangat erat kaitannya dengan program pengembangan budaya literasi". Pernyataan tersebut tentu sudah menjadi pengantar dalam mengenalkan isu yangh akan Sdiangkat. Sementara itu, argumen yang kuat terindikasi dalam pernyataan "Jika pengajaran sastra dilakukan secara tepat maka pengajaran sastra dapat memberikan sumbangan yang besar untuk memecahkan masalah-maslaah nyata yang cukup sulit untuk dipecahkan di masyarakat". Tulisan itu pun mencerminkan sumbersumber yang jelas sebagai fakta ketika ia berargumen. Rekomendasi juga disajikan secara jelas, yakni tercermin dalam pernyataan "Untuk itu, dibutuhkan upaya untuk menanggulangi program tumpang tindih 
antara budaya literasi dan pengajaran sastra."

Meskipun dalam berbagai aspek tulisan subjek 10 nyaris menampilkan kesempurnaan, dalam aspek ejaan masih banyak yang mendapat tinta merah. Masih banyak dijumpai ketidaktepatan penggunaan huruf kapital, seperti pada penulisan judul. Dalam naskah aslinya, tulisan subjek 10 menuliskan judul dengan huruf nonkapital, yang seharusnya ditulis kapital awal kata.

Dari data yang terkumpul diperoleh hasil analisis yang menunjukkan perbedaan angka nilai antara tes awal dan tes akhir, baik di kelompok kontrol, maupun kelompok eksperimen. Perbedaan itu dapat dilihat pada tabel berikut.

Tabel 2

Selisih Rata-rata Tes Awal dan Tes Akhir Kelas Eksperimen

\begin{tabular}{|c|c|c|c|c|}
\hline & KS & KIS & KK & KE \\
\hline $\begin{array}{c}\text { Rata-rata tes } \\
\text { awal } \\
\text { eksperimen }\end{array}$ & 1.3 & 1.36 & 2.6 & 0.58 \\
\hline $\begin{array}{c}\text { Rata-rata tes } \\
\text { akhir } \\
\text { eksperimen }\end{array}$ & 11.84 & 2.6 & 2.8 & 0.58 \\
\hline Gain & 0.54 & 1.24 & 0.2 & 0 \\
\hline
\end{tabular}

Dari tabel di atas, dapat diketahui bahwa peningkatan nilai terjadi pada semua aspek, kecuali aspek ejaan. Yang paling signifikan meningkat terjadi pada aspek kejelasan isi struktur. Peningkatan ini sangat dapat diterima, mengingat teknik $3 \mathrm{P}$ diawali oleh kegiatan peliputan. Melalu kegiatan ini penulis mengumpulkan informasi-informasi pendukung sehingga struktur isi semakin dapat digambarkan secara jelas. Yang disayangkan adalah aspek ejaan yang tidak meningkat sama sekali. Padahal, teknik 3P memfasilitasi penulis untuk mengecek ulang tulisan yang telah dibuatnya. Dengan demikian, yang diharapkan sebetulnya adalah penulis dapat memperbaiki aspek ejaan dengan lebih cermat.

Berdasarkan aspek penilaian, berikut ini perincian selisih nilai untuk hasil tes di kelas kontrol.
Tabel 3

Selisih Rata-rata Tes Awal dan Tes Akhir Kelas Kontrol

\begin{tabular}{|c|c|c|c|c|}
\hline & KS & KIS & KK & KE \\
\hline $\begin{array}{c}\text { Rata-rata } \\
\text { tes awal } \\
\text { kontrol }\end{array}$ & 1.24 & 1.42 & 2.1 & 0.54 \\
\hline $\begin{array}{c}\text { Rata-rata } \\
\text { tes akhir } \\
\text { kontrol }\end{array}$ & 1.28 & 1.64 & 1.64 & 0.5 \\
\hline Gain & 0.04 & 0.22 & -0.46 & -0.04 \\
\hline
\end{tabular}

Berbeda dengan yang terjadi pada kelas eksperimen, pada kelas kontrol, aspek yang meningkat hanya kelengkapan struktur dan kejelasan isi struktur. Peningkatannya pun tidak signifikasn. Bahkan, untuk aspek kesesuaian kaidah isi dan ketepatan ejaan mengalami penurunan nilai. Simpulan itu diperoleh dari adanya gain/selisih yang bernilai minus.

Selisih untuk rata-rata hasil tes akhir kelas kontrol dan kelas eksperimen adalah berikut.

Selisih Rata-rata Tes Akhir Kelas Kontrol dan Kelas Eksperimen

\begin{tabular}{|c|c|c|c|c|}
\hline & KS & KIS & KK & KE \\
\hline $\begin{array}{c}\text { Rata-rata tes } \\
\text { akhir control }\end{array}$ & 1.28 & 1.64 & 1.64 & 0.5 \\
\hline $\begin{array}{c}\text { Rata-rata tes } \\
\text { akhir } \\
\text { eksperimen }\end{array}$ & 1.84 & 2.6 & 2.8 & 0.58 \\
\hline Gain & 0.56 & 0.96 & 1.16 & 0.08 \\
\hline
\end{tabular}

dan Dari data-data di atas, pengujian hipotesis dilakukan dengan SPSS melalui uji $t$ dengan independen samples test yang sebelumnya telah dilakukan terlebih dahulu uji prasyarat, seperti normalitas dan homogenitas. Dari hasil uji t untuk pembuktian hipotesis, diketahui bahwa nilai signifikansi yang diperoleh adalah 0,000 yang artinya ada di bawah 0.05. Dengan demikian, dapat disimpulkan bahwa hipotesis yang diajukan diterima. Artinya, ada perbedaan yang signifikan antara kelompok satu dengan kelompok lainnya, yakni ada 
perbedaan yang signifikan antara kelas yang diberikan perlakuan dengan teknik $3 \mathrm{P}$ dengan yang tidak diberi perlakuan teknik 3P.

Seperti apa yang telah diuraikan sebelumnya, pembelajaran menulis teks editorial memang merupakan salah satu proses yang cukup komplek. Hal ini disebabkan oleh adanya proses penuangan ide dan gagasan yang tidak hanya berupa fakta, tetapi juga opini. Opini yang dituangkan pun bukan sekadar argumenargumen klise yang berkembang meluas tanpa disertai bukti konkret. Kompleksitas pembelajaran teks editorial menuntut tingkat pemahaman tinggi dari pembelajarnya. Oleh karena itu, sebelum pembelajar menuangkan ide dan gagasannya, ia harus memiliki informasi yang mumpuni terhadap topik yang akan dikembangkan. Selain itu, ia juga harus paham betul bagaimana struktur teks editorial itu sendiri. Kompleksitas ini seperti apa yang dikemukakan Kosasih (2014, hlm. 282) bahwa teks editorial biasanya ditulis oleh pimpinan redaksi yang memiliki pengalaman cukup tinggi. Senada dengan hal itu, Sumadiria (2011, hlm. 82) pun mengemukakan bahwa teks editorial atau tajuk rencana sebagai opini redaksi yang berisi aspirasi, pendapat, dan sikap resmi media pers terhadap persoalan potensial, fenomenal, aktual dan atau kontroversial yang terdapat dalam masyarakat, yang notabene pernyataan tersebut mengindikasikan bahwa teks editorial cukup kompleks.

Dari hasil tes yang telah diuraikan pada bagian sebelumnya, dapat diketahui bahwa ada perbedaan yang sangat mencolok antara kelas eksperimen dan kelas kontrol. Hal ini menunjukkan bahwa perlakuan yang diterapkan pada kelas eksperimen memberikan pengaruh terhadap kemampuan mahasiswa dalam menulis. Teknik $3 \mathrm{P}$ yang memfasilitasi siswa melakukan peliputan terlebih dahulu sebelum kegiatan menulis, secara langsung memberikan dampak yang positif terhadap penuangan fakta dan data dalam tulisan sehingga pada akhirnya sistematika penulisan menjadi lebih lengkap dan jelas.

Sekaitan dengan teknik pengumpulan data pada tahap prapenulisan, pada kelas kontrol pun sebenarnya dilakukan. Mahasiswa di kelas kontrol melakukan peliputan namun secara tidak langsung, berbeda halnya dengan kelas eksperimen.Yang menjadi permasalahan signifikannya perbedaan nilai kemampuan ditengarai karena adanya "konsep yang tidak lurus" dari mahasiswa mengenai jenis teks yang ditulis. Berbeda dengan pada saat tes awal ketika mahasiswa menulis teks editorial tanpa adanya beban struktur teks, pada tes akhir, tulisan mahasiswa di kelas kontrol cenderung menyuratkan adanya bagianbagian yang terlalu kontras antara fakta dan opini, yakni dengan adanya penyebutan sudut pandang dan sumber secara eksplisit. Bagian-bagian itu justru menjadi "pengganggu" dalam struktur teks sehingga kesan editorial menjadi kabur.

Sementara itu, dari aspek konten, jenis tajuk rencana yang ditulis oleh mahasiswa umumnya adalah tajuk rencana yang bersifat memberikan informasi semata dan yang bersifat menjelaskan. Padahal, Assegaff (Sumadiria, 2011, hlm. 884-86) menjelaskan bahwa selain jenis itu, tajuk rencana dapat bersifat memberikan argumenttasi, menjuruskan timbulnya aksi, bersifat jihad, bersifat membujuk, bersifat memuji, dan bahkan bersifat menghibur.Hal ini dapat terjadi karena memang kurang memadainya informasi atau pengetahuan dan pengalaman mahasiswa mengenai teks ilkareditorial citus sendiri.

Selain hal di atas, yang sangat disayangkan adalah banyaknya mahasiswa yang tidak memberikan judul dalam tulisannya. Padahal, dalam teks editorial, judul justru menjadi salah satu bagian yang sangat penting, seperti apa yang disebutkan Sumadiria (2011, hlm. 95). Dalam sumber tersebut, judul editorial atau tajuk rencana haruslah provokatif, singkat padat, relevan, fungsional, informal, representatif, dengan tetap merujuk pada bahasa baku. 
Terlepas dari masalah yang terjadi pada kelas kontrol sebagai kelas pembanding, permasalah-permasalahan yang tejadi pada kelas eksperimen membuktikan penuh bahwa langkah-langkah yang sistematis dan instruksi yang jelas dalam proses pembelajaran menjadi dasar penting bagi keberhasilan pembelajaran itu sendiri. Langkah yang sistematis memberikan pengalaman nyata yang mendorong pembelajar dalam hal ini mahasiswa meraih pengalaman positif.

Langkah-langkah sistematis yang dimaksud di atas bukan sekadar tahapantahapan yang dilalui tanpa arahan dan bimbingan. Sekalipun pembelajar melalui tahap-tahap yang telah direncanakan, jika ia tidak mendapat bimbingan maka hasilnya membuktikan tidak ada perubahan. Selain masalah konten, daya pengetahuan pembelajar sangat menentukan masalah teknis penulisan. Hasil tes membuktikan bahwa sekalipun ada kegiatan penyuntingan, jika mahasiswa tidak tahu konsep yang harus disunting maka hasilnya menjadi sama. Hal ini terbukti tidak adanya peningkatan yang signifikan dari hasil tes ditinjau dari aspek ejaan. Padahal, yang paling mudah disunting adalah aspek ejaan. Hal ini membuktikan bahwa pengetahuan ejaan mahasiswa yang menjadi sampel penelitian belum memadai.

Pada penulisan editorial "sesungguhnya" dalam media massa proses penulisan dari mulai prapenulisan hingga penyuntingan dilakukan dalam tim redaksi atau dengan kata lain dilakukan secara kolektif institusional seperti apa yang diuraikả Sumadiria (2011, hlm. 89-93). Sementara itu, dalam penelitian ini, khususnya ketika tes untuk menunjukkan kemampuan menulisnya, mahasiswa sebagai pembelajar dilatih secara individu. Dengan demikian, secara proses, ada kebelumtercapaian dengan apa yang diharapkan.

Terlepas dari apa yang telah diuraikan di atas secara hasil penelitian ini telah membuktikan bahwa penerapan teknik 3P lebih unggul dibandingkan dengan teknik konvensional (inkuiri). Hal itu terbukti dari adanya perbedaan yang signifikan antara kelas eksperimen dan kelas kontrol.

\section{PENUTUP \\ Simpulan}

Menjawab rumusan masalah yang diajukan, berdasarkan uraian hasil penelitian maka dapat ditarik simpulan bahwa teknik 3P (peliputan, penulisan, penyuntingan) efektif digunakan dalam pembelajaran menulis teks editorial. Simpulan ini diperoleh dari hasil pengujian statistik melalui uji $\mathrm{t}$ idenpendet sampel test yang memberikan nilai signifikansi $0,000<0,05$, yang artinya terdapat perbedaan menulis teks editorial antara kelas yang menggunakan dengan yang tidak menggunakan teknik 3P. Dari hasil analisis, dapat pula diketahui bahwa di kelas yang menggunakan teknik 3P, setiap aspek mengalami peningkatan, kecuali aspek ketepatan penggunaan ejaan. Aspek kelengkapan struktur teks meningkat sebesar 0,54 atau sebesar $13,5 \%$, kejelasan isi struktur teks meningkat 1,24 atau sebesar $31 \%$, ketepatan kaidah kebahasaan teks meningkat 0,2 atau sebesar 5\%. Di kelas kontrol, aspek kelengkapan struktur teks meningkat sebesar 0,04 atau sebesar 1\%, kejelasan isi struktur teks meningkat 0,22 atau sebesar 5,5\%, ketepatan kaidah kebahasaan teks mengalami penurunan, yakni $-0,46$ atau sebesar-11,5\% dan ketepatan penggunaan ejaan menurun -0,04 atau sebesar $-1 \%$. Dengan demikian, di kelas yang tidak menggunakan teknik $3 \mathrm{P}$ aspek yang meningkat hanya meliputi kedengkapan dan kejelasan struktur teks dan itupuntidak tebih dari $6 \%$.

\section{Saran}

Merujuk simpulan di atas, terdapat beberapa saran yang dapat diambil dari penelitian ini. Berikut saran yang dapat dipertimbangkan untuk pihak-pihak terkait.

1. Teknik 3P terbukti efektif meningkatkan kemampuan menulis teks editorial mahasiswa. Dengan demikian, guru dan siswa diharapkan dapat memanfaatkan teknik ini untuk pembelajaran menulis, tidak hanya 
untuk menulis teks editorial, tetapi juga untuk pembelajaran menulis lainnya.

2. Meskipun teknik 3P terbukti efektif, satu aspek penilaian, yakni penggunaan ejaan masih tidak mengalami peningkatan. Maka dari itu, diharapkan akan ada penelitian sejenis untuk lebih membuktikan mengenai teknik 3P dalam menulis, khususnya ditinjau dari peningkatan kemampuan pada aspek ejaan.

Sebagai bahan pertimbangan, teknik 3P dapat diimplementasikan dengan berbagai kreativitas. Sebagai contoh, pada tahap peliputan, pembelajar dapat bermain peran sebagai reporter dan mendokumentasikannya dalam video reportase atau bahkan film pendek. Melalui langkah ini, pembelajar diharapkan tidak hanya memperoleh informasi, melainkan juga memperoleh kesenangan dan kebermaknaan pembelajaran.

\section{DAFTAR PUSTAKA}

Cahyani, I. 2010. Pembelajaran menulis berbasis penelitian. Jurnal Bahasa dan Sastra Indonesia Vol. 10, No. 2, hlm. 162-174.

Harahap, E. M. 2014. Kemampuan menyunting karangan eksposisi berdasarkan ejaan, pilihan kata dan keterpaduan paragraf mahasiswa semester satu Prodi Pendidikan Bahasa dan Sastra Indonesia Universitas Muhammadiyah Tapanuli Selatan. Portal Garuda ISSN 2086 Volume 5 No. 2 Hlm. 36-57. Tersedia di http://down-load.portalgaruda.org/s Diakses tanggal 2 Februari 2017.

Kosasih, E. 2014. Jenis-jenis teks: analisis fungsi, struktur, dan kaidah serta langkah penulisannya. Bandung: Yrama Widya.

Mordekhay. 2009. Teknik peliputan, penulisan, dan penyuntingan berita 'perkotaan' pada harian umum berita kota. Laporan KKPL pada Fakultas Ilmu Komunikasi Universitas Indonesia Esa Unggul. Jakarta: Tidak diterbitkan. Tersedia di http://digi-
lib.esaunggul.ac.id/public/UEUNonDegree-4811-MORDEKHAY.pdf. Diakses tanggal 29 Januari 2017.

Parisi, K. 2014. Peningkatan kemampuan membaca kritis teks editorial dengan menggunakan metode membaca sq3r. Jurnal Ilmiah Mahasiswa DIKSATRASIA 1 Vol. 1 No. 1. Tersedia di http://www.unigal.ac.id/ejurnal/html/in dex.php?naon=805. Diakses pada 2 Februari 2017.

Sugiyono. 2012. Metode penelitian kuantitatif, kualitatif, dan $R \& D$. Bandung: Alfabeta.

Sumadiria, AS. H. 2011. Menulis artikel dan tajuk rencana. Bandung: Simbiosa Rekatama Media. 